\title{
The Impact of Teaching Factor on University Hospitals' Cost Structure: The Case of Greece
}

\author{
Georgios L. Thanasas \\ Dept. Accounting and Finance - TEI of Western Greece, Mesolonghi, 30200 Greece \\ *Corresponding Author: thageo@yahoo.gr
}

Copyright (C) 2014 Horizon Research Publishing All rights reserved.

\begin{abstract}
In this paper an attempt is made to determine the additional costs being undertaken by the University Hospitals of Greece in relation to those of General Hospitals. To determine the additional cost of University Hospitals, called teaching impact cost, a model of eight factors was constructed. The sample of examined Hospitals consists of fifty-three (53) Hospitals in Greece which issued financial statements for the years 2008-2009. This effort is intend to a direct comparison of the results that incurred in Greece, to other similar efforts that made in other European Countries. The results showed that the University Hospitals of Greece, similar to other European University Hospitals, face a higher operational cost compared to General Hospitals, which is due to education of the future health professionals.
\end{abstract}

Keywords Average Costs, Teaching Factor, Public Hospitals, University Hospitals, General Hospitals, Greece

\section{Introduction}

The need of government worldwide to decrease public expenditures led to the reform of public services, creating a new trend, which was named New Public Management. Although, the reductions of public expenditures raise concerns about who is responsible for these cuts ( $\mathrm{Wu}, 2010)$. On the other hand, New Public Management aimed to restructure the public sector by reducing operating costs and create a more efficient operation of the public sector. To achieve these incentives were created towards the adoption of public services outsourcing were adopted in order to increase competition and reduce costs. (Young and Macinati, 2012). New Public Management has increased the responsibility of the public administration and control; outcomes became more compelling, since it leads to improved performance by reducing bureaucracy (Ossege, 2012).

As expected, Health Sector could not be left out of the overall public sector's restructuring. Health care services are one of the most fundamental goods that governments around the world provide their citizens. Levaggi (2005) mentioned that in most developing countries, half of the total expenditures on health occur from hospital care accounts. The provision of health care is one of the most expensive goods that governments are asked to pay for; therefore the implementation of New Public Management's practices was welcomed by many countries. The direct goal was to reduce the operating costs of Hospitals while maintaining quality in health care.

Even though the plan to outsource Health Care services by implementing New Public Management was ambitious, various surveys (Hefetz and Warner, 2004; Whitten and Leiden, 2006), concluded that in the long-term neither the costs were reduced nor the quality of services improved, creating at the same time control problems. The result was the return in back sourcing and the internal rendering of services in the public sector (Young and Macinati, 2012). Young and Macinati (2009) showed in their research that $15 \%$ of Italians and $30 \%$ of Australian health providers turned to back sourcing. As a result to the above was the entrepreneurial approach to the public sector, by shifting the public sector services (including health services) to a less governmental base (Pollitt and Bouckaert, 2000).

Similar studies have been made in the past to other European Countries, like Spain and the Scandinavian Countries, although none of them compare the results to the others. This study, attempts to determine the same teaching impact cost as the other studies in Europe did in the past, but also compare the results of Greece, to the results of Spain and the Scandinavian Countries.

Furthermore, Greece since 2009 faces an economic crisis that has affected over the public debt. Public Health in Greece is one of the most costly sectors, therefore it is essential for government to cut this expense. The costs that University Hospitals in Greece face, are very high, because they have to teach the future personnel (medical and nurse). This study tries to find out if actually University Hospitals related to General Hospitals, face high costs, when the additional teaching cost extinct.

\section{Literature Review}


Over the years, as literature has covered the gap between Accounting and Cost Accounting in Hospitals, several researchers, especially from Europe, further emphasized the differences of the operating costs among hospitals. While in general terms, Hospitals of all types have similar characteristics and face almost the same operating costs, in various countries in Europe, several studies have investigated the fact that University Hospitals face higher operating costs than General Hospitals. This conclusion revealed the need to determine additional costs of University Hospitals and find the reason why this type of Hospitals had to spend more than General Hospitals.

University Hospitals as mentioned in literature have specific characteristics affecting their function and administration. These kinds of Hospitals have a threefold function to carry out, health care provision, teaching and research (Bevan and Rutten, 1987). However, the threefold function of University Hospitals complicates the management of the Hospital, especially when taking into account the different dynamics created by the individual operations that serve a University Hospital (Borgonovi, 2010).

The simultaneous provision of different services provided by University Hospitals emphasizes the crucial role play in Health Systems (Bluementhal et al. 1997), while reinforcing their organizational complexity compared to General Hospitals (Schreyogg and Von Reitzenstein, 2008). Besides, several studies emphasized the fact that the main use of the financial resources of University Hospitals is directly linked to their institutional and organizational framework: provision of specialized health services of high quality and innovative profile, teaching and research.

In Europe during the last decades where there is a tendency for spending cuts, the interest of research related to assessment and cost containment at the University Hospitals has increased, most likely led by the reforms in the health sector adopted by various European governments (Saltman and Figueras 1998). In addition several studies have focused on the need to manage the additional costs of University Hospitals to provide health care, by attempting to increase their level of effectiveness and efficiency through economic sustainability and more equitable reward systems (Lopez-Casasnovas and Saez, 1999; Linna e Hakkinen 2006).

The additional cost of University Hospitals is called Teaching Impact Cost and concerns the difference between the total costs of University Hospitals and General Hospitals. However, since the threefold function (health services, teaching and research) of University Hospitals occurs simultaneously, there is no way for a clear allocation of costs between the three different functions (Bevan, 1987; Foster, 1987; Lehner and Burgess, 1995; Perrin, 1987; Sloan et al., 1983). Despite the fact that there are different opinions among researchers concerning the interpretation of additional operating costs of University Hospitals, most researchers conclude that this additional cost refer to the Teaching Impact Cost (Grosskopf et al., 2001; Linna and
Hakkinen, 2006; Linna et al., 1998).

In Europe, the additional cost of University Hospitals (Teaching impact Cost) was measured in Spain (Lopez Casasnovas and Saez, 1999) and Scandinavian Countries (Norway, Finland, Sweden and Denmark, Medin et al., 2011). To determine the Teaching Impact Cost, the researchers splitted the Hospitals of the sample into two categories: University Hospitals and General Hospitals. Then, the total operating costs of these Hospitals were correlated with various operational factors, which affect the increase of the cost.

\section{Research Methodology}

Our research identifies the Teaching Impact Factor, which examines the additional costs faced by University Hospitals in relation to General Hospitals for the training of future medical and nurse personnel. Data were collected from the financial statements of fifty-three (53) Greek Public Hospitals over the 2008-2009 periods. Specifically, the sample consists of fifty-three (53) Public Hospitals in total, of which seven (7) are University and 46 General Hospitals.

Since the size of each hospital varies and in order to compare the cost between them their size should be transformed into the same basis in order to be comparable. To do this, the overall cost of each hospital was divided by its total beds. In that sense when the cost of a hospital is mentioned further in the analysis it refers to the cost per bed.

Further on, the descriptive statistics of the cost variable are presented. Picking from the central tendency measures we present the mean value, while from the dispersion measures we present the median (Median), the prevailing price (Mode), the standard deviation (St. Deviation), as well as the minimum and the maximum.

\section{Empirical Research}

From the Table 1, it appears that the average operating cost of University Hospitals is $25 \%$ higher than that of General Hospitals.

Table 1. Descriptive Statistics

\begin{tabular}{|c|c|c|}
\hline & General & University \\
\hline Mean & $184.572 €$ & $230.293 €$ \\
\hline Std. Dev & $79.529 €$ & $61.902 €$ \\
\hline Minimum & $79.529 €$ & $145.171 €$ \\
\hline Maximum & $606.267 €$ & $345.117 €$ \\
\hline Median & $170.769 €$ & $215.119 €$ \\
\hline Mode & $72.841 €$ & $145.171 €$ \\
\hline Range & $533.426 €$ & $199.947 €$ \\
\hline
\end{tabular}

The variables that are examined and will constitute the 
explanatory variables of the model are: the Teaching Impact Factor which informs about the type of the Hospital (either University or General), the number of Hospital beds, the length of stay (Hospital Activity), the average daily number of emergency (Emergency Activity), the daily schedule surgery, the medical and the nurse personnel as a present $\%$ of total workers and the Hospital occupancy as a present \%.

As it is obvious from the Table 2, in 2009 there was a great increase both of the daily surgeries $(+9,13 \%)$ and of the emergency activity in University Hospitals. The scheduled surgeries at University Hospitals are on average 40 per day, while in General Hospitals it is less by approximately $61 \%$ ( 15 day). Also, emergency activities at General Hospitals are lower by $51 \%$ compared to the University Hospitals, with an average of 311 surgeries a day.

On the contrary, the average length of stay has been reduced in both types of Hospitals for the year 2009, while we observe that there is not a large difference between the length of stay at University and General Hospitals. The number of beds has remained stable in both years (2008-2009); that is 279 for General and $\sim 667$ for University Hospitals.

Since the observations for MD (\% Medical staff), N (\% Nurses) \& CO (\% occupancy) are expressed in percentages and so as to control their distributions, they are grouped in categories and observations are made in order to be compared.

As far as the percentage of medical staff in hospitals (MD distributions) is concerned, it seems that at the $64.3 \%$ of the sample of University hospitals, the medical staff is $24 \%-30 \%$ of the total workforce, while at the $47.8 \%$ of the sample of General Hospitals the medical staff is $24 \%-38 \%$ of the total employees. It is further observed that there is a large discrepancy in the percentage of nursing staff to all employees (N Distribution) between the two hospitals. In $85.7 \%$ of the sample of university hospitals, the nursing staff is over $45 \%$, while the rate exceeds $43.5 \%$ of all general hospitals in our sample.

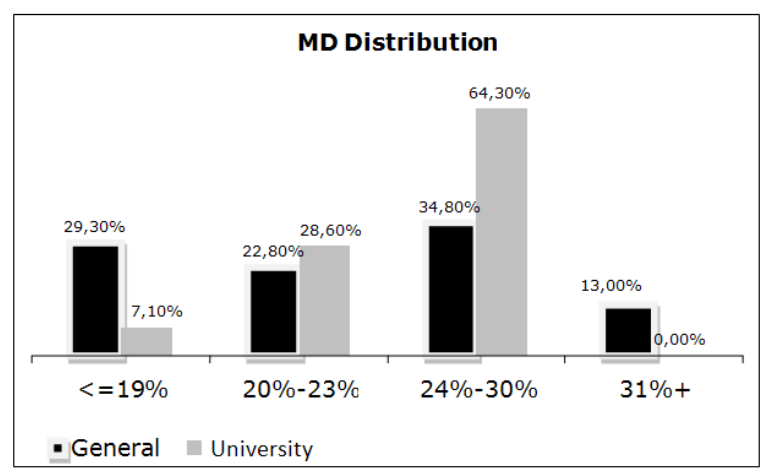

Figure 1. Distribution of Medical Personnel

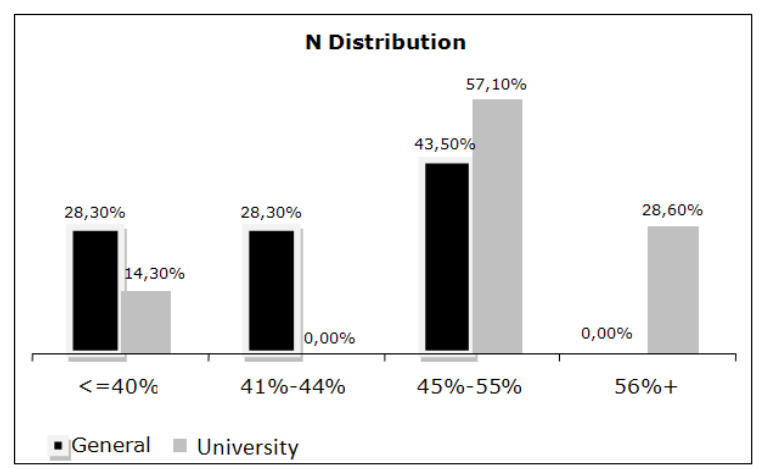

Figure 2. Distribution of Nurse Personnel

Table 2. Functional Factors of 2 types of Hospitals

\begin{tabular}{|c|c|c|c|c|c|c|}
\hline & & & 2008 & 2009 & Total & $\begin{array}{l}\text { Rate of change } \\
\text { from } 2008 \text { to } 2009\end{array}$ \\
\hline \multirow{4}{*}{$\begin{array}{l}\text { (Hospital } \\
\text { Activity) }\end{array}$} & \multirow{2}{*}{$\begin{array}{l}\text { General } \\
\text { Hospital }\end{array}$} & Mean & 3.76 & 3.73 & 3.74 & $-0.80 \%$ \\
\hline & & St. Deviation & 0.31 & 0.33 & 0.32 & \\
\hline & \multirow{2}{*}{$\begin{array}{l}\text { University } \\
\text { Hospital }\end{array}$} & Mean & 3.54 & 3.53 & 3.53 & $-0.28 \%$ \\
\hline & & St. Deviation & 0.47 & 0.56 & 0.5 & \\
\hline \multirow{4}{*}{$\begin{array}{c}\text { (Emergency } \\
\text { Activity) }\end{array}$} & \multirow{2}{*}{$\begin{array}{l}\text { General } \\
\text { Hospital }\end{array}$} & Mean & 152.91 & 151.93 & 152.43 & $-0.64 \%$ \\
\hline & & St. Deviation & 110.04 & 110.44 & 109.63 & \\
\hline & \multirow{2}{*}{$\begin{array}{c}\text { University } \\
\text { Hospital }\end{array}$} & Mean & 304.71 & 318.29 & 311.5 & $4.46 \%$ \\
\hline & & St. Deviation & 118.06 & 116.09 & 112.71 & \\
\hline \multirow{4}{*}{ (Surgical) } & \multirow{2}{*}{$\begin{array}{l}\text { General } \\
\text { Hospital }\end{array}$} & Mean & 15.22 & 15.33 & 15.27 & $0.72 \%$ \\
\hline & & St. Deviation & 18.04 & 17.86 & 17.85 & \\
\hline & \multirow{2}{*}{$\begin{array}{c}\text { University } \\
\text { Hospital }\end{array}$} & Mean & 37.57 & 41 & 39.29 & $9.13 \%$ \\
\hline & & St. Deviation & 9.07 & 8.35 & 8.56 & \\
\hline \multirow{4}{*}{ Number of Beds } & \multirow{2}{*}{$\begin{array}{l}\text { General } \\
\text { Hospital }\end{array}$} & Mean & 279 & 279 & 279 & $0.00 \%$ \\
\hline & & St. Deviation & 209.38 & 209.38 & 208.23 & \\
\hline & \multirow{2}{*}{$\begin{array}{c}\text { University } \\
\text { Hospital }\end{array}$} & Mean & 666.86 & 666.86 & 666.86 & $0.00 \%$ \\
\hline & & St. Deviation & 128.81 & 128.81 & 123.76 & \\
\hline
\end{tabular}


Respectively, it is observed that there is a wide deviation at the rate of occupancy of Hospitals (CO Distribution). In $85.7 \%$ of the sample of University Hospitals, completeness exceeds $73 \%$, while the rate exceeds $44.5 \%$ of all General Hospitals of the sample. In the remaining $55.5 \%$ of the sample of general hospitals, the occupancy rate is between $58 \%-72 \%$.

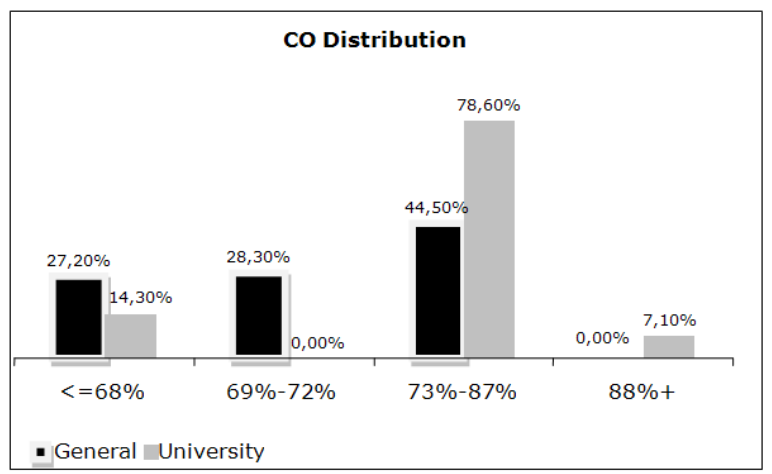

Figure 3. Distribution of Hospitals' Occupancy

Table 3. Medical and Nurse Personnel of Hospitals

\begin{tabular}{|c|c|c|c|c|}
\hline & \multicolumn{2}{|c|}{ General } & \multicolumn{2}{c|}{ University } \\
\hline & Minimum & Maximum & Minimum & Maximum \\
\hline MD & 0.05 & 0.38 & 0.17 & 0.29 \\
\hline $\mathrm{N}$ & 0.24 & 0.55 & 0.34 & 0.56 \\
\hline $\mathrm{CO}$ & 0.58 & 0.86 & 0.66 & 0.93 \\
\hline
\end{tabular}

After that, a t-test hypothesis will be performed to determine if the explanatory variables differ significantly between the University Hospitals and General Hospitals. To proceed to the t-test controls, we need to check whether our variables follow the normal distribution. Checking regularity in the Table 4 (Test of Normality) shows that only when the p-value is large $(>0.05)$ and the null hypothesis is not rejected that the residuals follow a normal distribution. Variables that are marked in red do not follow a normal distribution, therefore we will do other non-parametric tests (e.g., Mann-Whitney), to investigate whether there are statistically significant differences between the two types of Hospitals.

Table 5, shows the averages of t-test and the results of a test for equality of variance of quantitative variables between the University and General Hospitals. This test is called "Levene's Test for Equality of Variance" and when the value of sig. in Levene's Test is to be $<0.05$, it is assumed that the variations between the two groups participating of the analysis are different. So, in order to draw safe conclusions we will use the line indicating "Equal Variance Not Assumed". When the value of sig. is greater than 0.05 means that the hypothesis of equality of the two groups is valid and when the value of sig. in this line is $<0.05$ we reject the null hypothesis and we accept that the two groups differ significantly.

According to the Table 6 and based on what was mentioned above, the variables that differ significantly between University Hospitals and General Hospitals are the number of nurses as a presentence $(\mathrm{N})$ of the total personnel and the Hospital occupancy (CO). Moreover, due to non parametric tests it seems that there is no statistically significant difference in medical staff as a presentence of the University and General Hospitals.

Table 4. Test of Kolmogorov-Smirnov

One-Sample Kolmogorov-Smirnov Test

\begin{tabular}{|c|c|c|c|c|c|c|c|c|}
\hline & & $\begin{array}{c}\text { Number of } \\
\text { beds }\end{array}$ & $\begin{array}{c}\text { Length of } \\
\text { stay }\end{array}$ & $\begin{array}{l}\text { Emergency } \\
\text { Activity }\end{array}$ & $\begin{array}{c}\text { Daily } \\
\text { Surgery }\end{array}$ & $\begin{array}{l}\text { Medical } \\
\text { Personal } \\
\end{array}$ & $\begin{array}{l}\text { Nurse } \\
\text { Personal } \\
\end{array}$ & $\begin{array}{l}\text { Hosptaal } \\
\text { Occupancy }\end{array}$ \\
\hline $\mathrm{N}$ & & 106 & 106 & 106 & 106 & 106 & 106 & 106 \\
\hline \multirow[b]{2}{*}{ Normal Parameters } & Mean & 330,2264 & 3,7167 & 173,4340 & 18,4434 & ,2308 & 4336 &, 7263 \\
\hline & $\begin{array}{c}\text { Std. } \\
\text { Deviation }\end{array}$ & 238,5025 & ,34958 & 122,13849 & 18,76323 &, 05548 & ,07172 & 06878 \\
\hline \multirow{3}{*}{ Most Extreme Differences } & Absolute &, 173 & ,086 & ,205 &, 182 &, 160 & ,096 & 077 \\
\hline & Positive &, 173 &, 077 & ,205 &, 182 &, 160 &, 042 &, 077 \\
\hline & Negative &,- 147 &,- 086 &,- 120 &,- 176 &,- 144 &,- 096 &,- 075 \\
\hline \multirow{2}{*}{$\begin{array}{c}\text { Kolmogorov-Smirnov Z Asymp. } \\
\text { Sig. (2-tailed) }\end{array}$} & & 1,782 & ,888 & 2,112 & 1,870 & 1,644 & ,984 & ,792 \\
\hline & &, 003 & ,410 &, 000 &, 002 & ,009 & 288 &, 557 \\
\hline
\end{tabular}

a. Test distribution is Normal.

b. Calculated from data. 
Table 5. T-Test and Levene's Test

Independent Samples Test

\begin{tabular}{|c|c|c|c|c|c|c|c|c|c|c|}
\hline & \multicolumn{2}{|c|}{$\begin{array}{c}\text { Levene's Test for } \\
\text { Equality of Variances }\end{array}$} & \multicolumn{7}{|c|}{ t-test for Equality of Means } \\
\hline & & \multirow{2}{*}{$\mathrm{F}$} & \multirow{2}{*}{ Sig } & \multirow{2}{*}{$\mathrm{t}$} & \multirow{2}{*}{$\mathrm{df}$} & \multirow{2}{*}{$\begin{array}{c}\text { Sig. } \\
\text { (2-tailed } \\
\text { ) }\end{array}$} & \multirow{2}{*}{$\begin{array}{l}\text { Mean } \\
\text { Differen } \\
\text { ce }\end{array}$} & \multirow{2}{*}{$\begin{array}{c}\text { Std. } \\
\text { Error } \\
\text { Differen } \\
\text { ce }\end{array}$} & \multicolumn{2}{|c|}{$\begin{array}{c}95 \% \text { Confidence Interval of } \\
\text { the Difference }\end{array}$} \\
\hline & & & & & & & & & Lower & Upper \\
\hline \multirow[b]{2}{*}{$\begin{array}{l}\text { Lengh of } \\
\text { Stay }\end{array}$} & $\begin{array}{c}\text { Equal } \\
\text { variances } \\
\text { assumed }\end{array}$ & 4,516 &, 036 & 2139 & 104 &, 035 & ,21099 & ,09862 &, 01543 & ,40656 \\
\hline & $\begin{array}{c}\text { Equal } \\
\text { variances } \\
\text { not } \\
\text { assumed }\end{array}$ & & & 1535 & 14617 & ,146 & ,21099 & , 13748 &,- 08270 & ,50469 \\
\hline \multirow[b]{2}{*}{$\begin{array}{c}\text { Nurse } \\
\text { Personnel }\end{array}$} & $\begin{array}{c}\text { Equal } \\
\text { variances } \\
\text { assumed }\end{array}$ & ,231 &, 0632 & -4330 & 104 &, 000 &,- 08240 & ,01903 &,- 12014 &,- 04467 \\
\hline & $\begin{array}{c}\text { Equal } \\
\text { variances } \\
\text { not } \\
\text { assumed }\end{array}$ & & & -3837 & 19984 &, 001 &,- 08240 &, 02147 &,- 12793 &,- 03687 \\
\hline \multirow[b]{2}{*}{$\begin{array}{l}\text { Hospital; } \\
\text { Occupancy }\end{array}$} & $\begin{array}{c}\text { Equal } \\
\text { variances } \\
\text { assumed } \\
\end{array}$ &, 506 & ,478 & -2585 & 104 &, 011 &,- 04968 & ,01922 &,- 08779 &,- 01157 \\
\hline & $\begin{array}{c}\text { Equal } \\
\text { variances } \\
\text { not } \\
\text { assumed }\end{array}$ & & & -2.597 & 17257 &, 019 &,- 04968 & 01913 &,- 08999 &,- 00937 \\
\hline
\end{tabular}

Table 6. Non Parametric Tests

Test Statistics $^{\mathrm{a}}$

\begin{tabular}{|c|c|c|c|c|}
\hline & Number of beds & Emergency Activity & Daily Surgery & Medical Personnel \\
\hline Mann-Whitney U & 88,000 & 205,500 & 143,000 & 521,000 \\
\hline Wilcoxon W & 4366,000 & 4483,500 & 4421,000 & 4799,000 \\
\hline Z & $-5,191$ & $-4,092$ & $-4,681$ & $-1,148$ \\
\hline Asymp. Sig. (2-tailed) &, 000 &, 000 &, 000 &, 251 \\
\hline
\end{tabular}

a. Grouping Variable: Teaching Impact Factor

\section{Determination of Teaching Impact Factor}

In order to determine the cost of Teaching Impact Factor, a dummy variable with values 1 (University Hospital) and 0 (General Hospital) was introduced and in order to separate the year, we use the usual choice of 0-1 dummy index.

In order for the model to be valid, some assumptions must be made. First of all there must be equality of variations (homoskedasticity) and thereafter the residuals should follow a normal distribution with zero mean and constant variance. Also, there has to be independent residuals. In addition, the correlation of the residuals with the independent variables should be 0 and finally there should be no linear correlation between the explanatory variables.

However, from the results of the regression analysis, we observe that the assumptions of normality are being violated (both two tests Kolmogorov-Smirnov and Shapiro-Wilks gives $\mathrm{p}$-value $<0,05$ when the null hypothesis is rejected claiming that the remains of the model follow a normal distribution). Furthermore, homoskedasticity also violated, since the residuals versus the explanatory variables seem to have a trend and may not be random.

In order to correct the two cases, we use some transformations either to the dependent variables or to the explanatory variables, or to both. After testing the model in study, we found that it is best to tackle both the dependent and some explanatory variables. As transformation we used the logarithm of cost and from now on the dependent variable is the logarithm of the cost, while the explanatory variable which was transformed by taking the logarithm is the number of beds (SD), the average daily number of emergency (Emergency Activity) and daily scheduled surgeries (Surgical). After determining the variables that are involved in construction process of the model, we checked the satisfaction criteria applying to this kind of regression.

To implement the test, we classify each observation of each variable in ascending order and remove fourteen 
observations in the center. We calculated for each subset (46 observations in each subset) the statistical $\mathrm{F}$ and divide the two $\mathrm{F}$ statistics placing on the numerator the greater variation. The results are shown on the Table 7:

Table 7. Test of Goldfeld-Quant

\begin{tabular}{|c|c|c|c|}
\hline & \multicolumn{3}{|c|}{ Residual Sum of Squares } \\
\hline & Sample $<42$ & Sample $>60$ & F Test \\
\hline In(SD) & 5,076 & 4,782 & 1,061 \\
\hline Hospital Activity & 4,459 & 6,45 & 1,447 \\
\hline In(Emergency Act.) & 5,095 & 6,144 & 1,206 \\
\hline In(Surgical Act.) & 7,106 & 4,444 & 1,599 \\
\hline MD & 6,928 & 4,55 & 1,523 \\
\hline $\mathrm{N}$ & 6,112 & 4,69 & 1,303 \\
\hline CO & 2,804 & 7,752 & 2,765 \\
\hline
\end{tabular}

If $\mathrm{F}=<\mathrm{F} \sim 1,6$ we do not reject the null hypothesis of homoskedasticity, so the disturbance term is not characterized by heteroscedasticity. The only variable that yields heteroscedasticity is the number of presentence of Hospital's occupancy (CO). The test of normality of residuals in the Table 8 shows that the p-value is large ( $>$ $0.05)$, therefore the null hypothesis that the residuals follow a normal distribution is not rejected.

Table 8. Test of Normality

\begin{tabular}{|c|c|c|c|c|c|c|}
\hline & \multicolumn{3}{|c|}{ Kolmogorov-Smirnov(a) } & \multicolumn{3}{|c|}{ Shapiro-Wilk } \\
\cline { 2 - 7 } & Statistic & df & Sig. & Statistic & df & Sig. \\
\hline $\begin{array}{c}\text { ZRE_1 } \\
\text { Standardized } \\
\text { Residual }\end{array}$ &, 065 & 106 &, $200(*)$ &, 981 & 106 &, 122 \\
\hline
\end{tabular}

The following histogram graphically confirms that the observations follow the normal distribution.

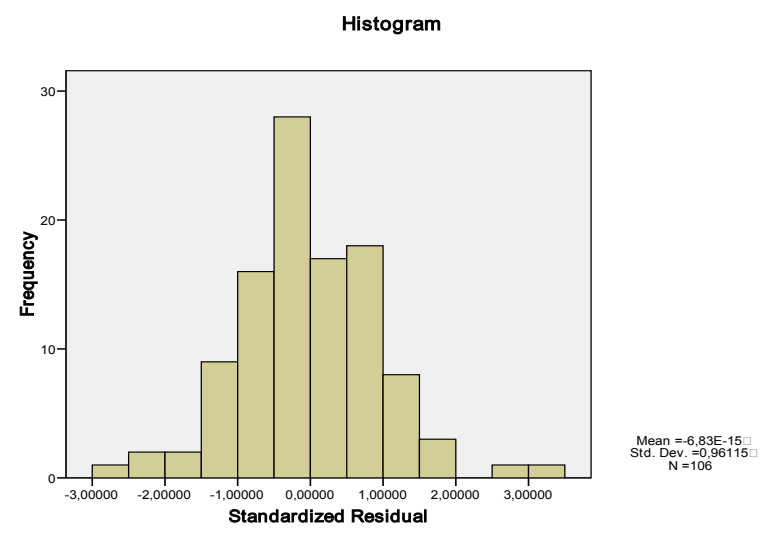

Figure 4. Histogram-Test of Normality

To test the independence of residuals, we used a graph of predicted values versus residuals. Because of the fact that the points of the scatterplot appear to be random, we conclude that there is independence.

Also, Table 9 confirms the hypothesis that the correlations of residuals with the explanatory variables are zero.

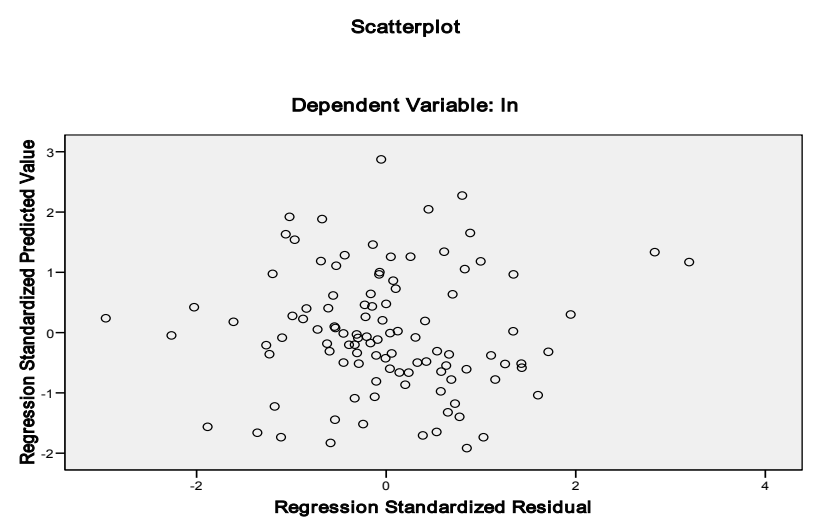

Figure 5. Predicted values compared to residuals

Table 9. Residual Correlation

\begin{tabular}{|c|c|c|}
\hline & & Standardized Residual \\
\hline \multirow{3}{*}{$\ln \_s d$} & Pearson Correlation & 0,00 \\
\hline & Sig. (2-tailed) & 1,00 \\
\hline & $\mathrm{N}$ & 106 \\
\hline \multirow{3}{*}{ In_Emergency_Activity } & Pearson Correlation & 0,00 \\
\hline & Sig. (2-tailed) & 1,00 \\
\hline & $\mathrm{N}$ & 106 \\
\hline \multirow{3}{*}{ ln_Surgical } & Pearson Correlation & 0,00 \\
\hline & Sig. (2-tailed) & 1,00 \\
\hline & $\mathrm{N}$ & 106 \\
\hline \multirow{3}{*}{ length of stay } & Pearson Correlation & 0,00 \\
\hline & Sig. (2-tailed) & 1,00 \\
\hline & $\mathrm{N}$ & 106 \\
\hline \multirow{3}{*}{$\%$ medical personnel } & Pearson Correlation & 0,00 \\
\hline & Sig. (2-tailed) & 1,00 \\
\hline & $\mathrm{N}$ & 106 \\
\hline \multirow{3}{*}{$\%$ nurse personnel } & Pearson Correlation & 0,00 \\
\hline & Sig. (2-tailed) & 1,00 \\
\hline & $\mathrm{N}$ & 106 \\
\hline \multirow{3}{*}{ \%hospital occupancy } & Pearson Correlation & 0,00 \\
\hline & Sig. (2-tailed) & 1,00 \\
\hline & $\mathrm{N}$ & 106 \\
\hline
\end{tabular}

Finally, we have to test that there is no linear correlation between the explanatory variables. This can be diagnosed with a measure called VIF and equals 1 / ( 1 - Ri), where $\mathrm{Ri}$ is the correlation coefficient for each pair of explanatory variables. This fact practically indicates the speed with which one increases the variance estimator when there is linear correlation between the explanatory variables. For values greater than 10 , there is a serious problem of linear correlation. Additionally, if a variable is not related to the other, then Tolerance $=1$, while if there is a perfect correlation of a variable with the other then Tolerance $=0$, (Tolerance $=1 / \mathrm{VIF})$. At this point it should be noted that two variables are perfectly independent. 
Table 10. Coefficient matrix

\begin{tabular}{|c|c|c|c|c|c|}
\hline & & & & $\begin{array}{c}\text { Collonearity } \\
\text { Statics }\end{array}$ & \\
\hline & $\begin{array}{c}\text { Standardized } \\
\text { Coefficients } \\
\text { Beta }\end{array}$ & $\mathrm{t}$ & Sig. & Tolerance & VIF \\
\hline (Constant) & & 13,923 & 0 & & \\
\hline Ln_Sd & $-0,527$ & $-2,432$ & 0,017 & 0,162 & 6,169 \\
\hline Ln_Emergency_Activit & 0,292 & 1,343 & 0,182 & 0,162 & 6,193 \\
\hline y & $-0,099$ & $-0,599$ & 0,55 & 0,277 & 3,608 \\
\hline Ln_Surgical & 0,08 & 0,798 & 0,427 & 0,76 & 1,317 \\
\hline Hospital_Activity & $-0,232$ & $-1,787$ & 0,077 & 0,45 & 2,222 \\
\hline MD & 0,25 & 2,134 & 0,035 & 0,556 & 1,798 \\
\hline N & 0,558 & 4,541 & 0 & 0,504 & 1,984 \\
\hline CO & 0,238 & 2,129 & 0,036 & 0,609 & 1,642 \\
\hline TEACH & 0,124 & 1,423 & 0,158 & 0,996 & 1,004 \\
\hline Year & $R^{2}=27 \%$, Dependent: LN(Cost), Durbin Watson: 1,909 & & & \\
\hline
\end{tabular}

The $R^{2}$ ratio is an indication of samples' variance size that is explained by the regression. Based on the above, we observe that the model explains only $27 \%$ of the total variance. The Durbin Watson test was applied to investigate the problem of autocorrelation. Autocorrelation indicates a certain degree of correlation between successive values of the random error. Because of the fact that the value of the Durbin Watson test is close to two, there is not an autocorrelation problem.

From the Table 10 of Coefficients above, we observe that the variables appearing to be statistically significant for the model are the number of beds (SD), the nursing staff as a percentage of all workers $(\mathrm{N})$, the hospital occupancy as a percentage (CO) and the Teaching Impact Factor (TEACH).

To see whether these variables contribute to the effect of the cost of hospitals, we observe the Standardized Coefficients, for which the corresponding variables are converted into the same scale so that they can be compared.

The constant $(10252)$ is the value at which the linear of least squares intersects the vertical coordinate axis. If we increase the number of beds in a unit and keep all the other effects constant, the rate of the number of beds (Ln_SD) $(-0,527)$ indicates a decrease in the expected average cost. Furthermore, the rate of nurses $(\mathrm{N})(0,25)$ indicates that every unit increases in personnel costs cause the logarithmic increase by 0,25 units keeping other effects constant. Moreover, for every unit increase in hospital occupancy (CO), it is expected that the cost will increase by 0.558 units. Finally, the factor of teaching impact refers to the additional cost increase by 0.238 units when is a University Hospital, keeping other effects constant.

Lopes - Casasnovas and Saes (1999), determined the teaching impact factor of Spain to $15 \%$, while Medin et al. (2011) found that the same factor in Finland is 4,66\%, in Sweden is $4,01 \%$, in Denmark is $12,7 \%$ and finally in Norway is $31,51 \%$. From the comparison of all the presentences it is obvious that Greece has the second largest teaching impact factor on Hospital costs (after Norway). But we have to notice that Greece has also the lowest number of University Hospitals to the above countries. This means that Greece spends much more amounts than any other from the above countries for training the future hospital personnel.

\section{Conclusions}

In this paper we performed a comparative analysis of the cost between University Hospitals and General Hospitals in Greece. As mentioned above, seven (7) University Hospitals of Greece and 46 General Hospitals were examined. All hospitals issue financial statements for the period of the study and also lie to the same regions.

Initially, the research is focused on identifying the percentage of cost that University Hospitals spend compared to the General Hospitals in order to train the students of Medical and Nurse Departments. For this reason, several factors which would constitute to the econometric model for the development of the study were selected from international literature. After the tests that were carried out (eg $t$ - test, Test of Normality, etc.), some factors that correlate were excluded from the survey and after that we found those variables that are statistically significant and contribute to the impact of the cost. Finally, the following factors were used for the research: the number of beds (SD), the nursing staff as a percentage of all workers $(\mathrm{N})$, the occupancy as a percentage of the Hospital (CO) and factor TEACH.

Thus based on the analysis above, the teaching impact factor increases the cost of the University Hospitals by 0.238 or 23.8 percent. In absolute numbers, the teaching impact factor costs 195.02 Euros per bed per day.

Regarding other statistically significant factors affecting the model, the increase in the number of beds by one unit causes a decrease in average cost by 0.527 or 52.7 percent. In 
monetary terms, an increase in the number of beds will reduce costs by 431.82 Euros per bed per day. For nurse personnel, the survey showed that for every unit increase, costs are expected to rise by 0.25 or by 25 percent, while denominated in Euros it is 204.85 per bed per day. Finally, for Hospital occupancy an increase of one unit the cost increase is expected to be around 0.558 or 55.8 percent and in monetary terms about 457.23 Euros per bed per day.

To sum up, the present study confirms the general rule that applies to literature and relates to the fact that the larger the hospital, the lower the cost spent per bed. This is concluded due to the fact of the existence of economies of scale, since the health services offered by a large hospital are considerably better in whole and have the effect of concentration of population in large versus small hospitals. Thereby, as the number of cases treated by large Hospital increase, scale economies emerge. As a consequence and based on the results of this survey a question of redefining health policies by the policymakers arises.

\section{REFERENCES}

[1] Bevan, G. (1987). Financing the additional service costs of teaching English medical students by the service increment for teaching (sift): an exposition and critique, Financial Accountability \& Management, 3(2).

[2] Bevan, G. and Rutten, F. (1987). The organisation and Functions University Hospital in Different Countries, Finance Accountability \& Management, 3(2).

[3] Bluementhal, D., Campbell, E.G. and Weissman, J.S. (1997). The Social mission of Academic Health Centres, New England Journal of Medicine, 337, 1150-1553.

[4] Borgonovi, E. (2010). Postfazione, In Carbone C., Lega F. and Prenestini A., eds, Governance e organizzazione delle Aziende Ospedaliero-Universitarie, Egea, Milano.

[5] Foster, M.J. (1987). On estimating the costs of the products of teaching hospitals: a review of the literarture, Financial Accountability \& Management, 3(2)

[6] Grosskopf, S., Margatitis, D. and Valdmanis, V. (2001). Comparing Teaching and Non-teaching Hospitals: A Frontier Approach (Teaching vs. Non-teaching Hospitals), Health Care Management Science, 4, 83-90

[7] Hefetz, A. and Warner, M. (2004) Privatization and its Reverse: Explaining the Dynamics of the Government Contracting Process, Journal of Public Administration Research and Theory, 14 (2), 171-90.

[8] Lehner, L.A. and Burgess, J.F. (1995). Teaching and hospital production: the use of regression estimates, Health Economics, 4, 113-125.
[9] Levaggi, R. (2005). Hospital Health Care: Pricing and Quality Control in a Spatial Model with Asymmetry of Information, International Journal of Health Care Finance and Economics, 5, 327-349.

[10] Linna, M. and Hakkinen, U. (2006). Reimbursing for the costs of teaching and research in Finnish hospitals: A stochastic frontier analysis, International Journal of Health Care Finance and Economics, 6, 83-97.

[11] Linna, M., Hakkinen, U., Linnakko, E. (1998). An econometric study of cost of teaching and research in Finnish Hospitals, Health Economics, 7 (4), 291 - 305.

[12] Lopez - Casasnovas, G., Saez, M. (1999). The impact of teaching status on average costs in Spanish Hospitals, Health Economics, 8 (7), 641 - 651.

[13] Macinati, M. and Young, S. (2009) International Perspectives in Backsourcing: Is it Just a Merry-go-Round?, Health Care Management Review, 34 (4), 372-82.

[14] Medin, E., Anthum, K.S., Hakkinen, M., Kittelsen, S.A.C., Linna, M., Magnusen, J., Olsen, K., Rehnberg, C. (2011). Cost efficiency of university hospitals in the Nordic Countries: A cross country analysis, European Journal of Health Economics, 12, 509 - 519 .

[15] Ossege, C. (2012). Accountability - are we better off without it?, Public Management Review, 14 (5), 585-607.

[16] Perrin, J. (1987). The costs and joint products of English teaching hospitals, Financial Accountability \& Management, $3(2)$.

[17] Pollitt, C. and Bouckaert, G. (2000). Public Management Reform: A Comparative Analysis, Oxford University Press, 2000 .

[18] Saltman, R.B. and Figueras, J. (1998). Analyzing the evidence on European health care reforms, Health Affairs, 17(2).

[19] Schreyogg, J. and Von Reitzenstein, C. (2008). Strategic groups and performance differences among academic medical centers, Health Care Management Review, 33(3), 225-233.

[20] Sloan, F., Feldman, R. and Steinwald, A. (1983). Effects of Teaching on Hospital Costs, Journal of Health Economics, 2 , $1-28$.

[21] Young, S. and Macinati, M., (2012). Health Outsourcing/Backsourcing: Case Studies in the Australian and Italian Health Sector, Public Management Review, 14(6), pp. 771-794.

[22] Whitten, D. and Leidner, D. (2006). Bringing IT Back: An Analysis of the Decision to Backsource or Switch Vendors, Decision Sciences, 37 (4), 605-21.

[23] Wu, Y.V. (2010). Hospital cost shifting revisited: new evidence from the balanced budget act of 1997, International Journal of Health Care Finance and Economics, 10, 61-83. 